\title{
ABCESUL RETROFARINGIAN ŞI ABCESUL LATERO-CERVICAL PROFUND. DIFICULTĂṬI DE DIAGNOSTIC LA COPIL
}

\author{
Bauer Adalbert ${ }^{1}$ \\ ISCM Caritas Medica, medic primar pediatru, doctor în medicină
}

\begin{abstract}
Although the abscess of retropharynx and the profound cervical area have a characteristic simptomatology, often not recognized, a simple inspection of one objective clinical examination being insufficient. Not tracking down the affections, or an erroneus diagnosis, may have negative consequences, these being the reason to debate them.
\end{abstract}

Key words: abscess of retropharynx, profound cervical abscess.

Rezumat: $\mathrm{Cu}$ toate că abcesul retrofaringian și abcesul latero-cervical profund au o simptomatologie caracteristică, de multe ori nu sunt recunoscute, o inspecție simplă la examenul clinic obiectiv nefiind suficientă. Nedepistarea afecțiunilor sau diagnosticul eronat pot avea consecințe nefaste, acesta fiind motivul punerii lor în discuție.

Cuvinte cheie: abcesul retrofaringian, abcesul latero-cervical profund.

Voi trata aceste două entități separat, findcă ele prezintă particularități de vârstă privind simptomele clinice și evoluția.

\section{Abcesul retrofaringian}

Mascat adesea de simptomele corizei, adenoiditei cauzale, sau de cele ale otitei sau bronhopneumoniei la un sugar sau copil antepreșcolar, debutul abcesului retrofaringian poate trece neobservat, fapt care ne obligă să controlăm cu multă atenție peretele posterior al faringelui.

Abcesul retrofarinian este adenoflegmonul ganglionilor Gilette, situați în țesutul celular al spațiului prevertebral.

\section{Etiologie}

Cauza determinantă a abcesului retrofaringian o constituie rinitele și adenoiditele acute banale ale primei copilării. Cauzele favorizante sunt: rezistența scăzută a organismului la sugar, alimentația incorectă, frigul, mediul epidemic. Agentul patogen este de obicei streptococcul sau pneumococcul. Se întâlnește mai des în primii doi ani de viață.

Abcesul retrofaringean poate fi suspectat când copilul, de cele mai multe ori febril, după ce trage de câteva ori la piept sau din biberon, refuză mâncarea, laptele refulează din cauza disfagiei, apoi își face apariția un zgomot respirator caracteristic: tiraj, stridor faringian, uneori și cornaj inconstant, însoțit de raluri buloase. Copilul când plânge are vocea nazonată, „crocănitul de cioară”. Redoarea cefei la hiperextensie, împreună cu febra, pot să ducă la un diagnostic eronat de meningită. Respirația este dificilă, uneori cu accese de asfixie și cianozare.

Diagnosticul va fi confirmat prin palpare: o proeminență de forma unei hemisfere, situată pe peretele posterior, pe linia mediană, sau deseori ceva mai lateral. Palparea ne informează în același timp și asupra consistenței tumorii (dacă este colectată). Bombarea mai accentuată a unei tumori situate mai sus, poate 
fi recunoscută chiar și numai cu ajutorul inspecției. Uneori mai este prezentă și o tumefacție exterioară pe marginea posterioară a sternocleidomastoidianului. Situarea joasă a abcesului pe peretele posterior al hipofaringelui face dificilă punerea în evidență la bucofaringoscopie, necesitând examenul cu oglinda sau directoscopia. Alt simptom la fel de timpuriu este torticolisul, contractura care nu permite mobilizarea capului copilului, putând fi confundată cu adenopatia laterocervicală. În cazuri mai severe, în paralel cu simptomatologia locală, starea generală se alterează, furnizînd tabloul unei stări toxico-septice.

Abcesul retrofaringian poate fi confundat, mai ales dacă este situat la nivelul hipofaringelui, datorită importantelor tulburări respiratorii, cu toate laringopatiile dispneizante ale sugarului sau copilului mic, ca: laringita subglotică edematoasă, laringotraheita fibrinoasă, crupul difteric, gripal sau rujeolic, corpi străini laringieni, stridorul congenital, etc.

Tratamentul este complex, dar în primul rând chirurgical. Până la colectare, conduita poate fi de expectativă. De multe ori adenitele regresează spontan. După colectare, având senzația de fluctuație netă, se va proceda la incizie.

\section{Abcesul laterocervical profund}

Are o incidență crescută la copilul școlar, în general prin mecanism de extindere al unui proces infecțios peritonsilar, la copii cu imunitate deficitară. Este caracterizat de predominența fenomenelor cervicale față de cele faringiene și debutează prin simptomele afecțiunii cauzale: disfagie și odinofagie intense, febră de tip septic și stare generală alterată. În general apare după o amigdalită acută, formă clinică septică, sau în cursul bolilor infecțioase anergizante, flegmon periamigdalian nedepistat, etc.

Simptomele clinice generale se amendează treptat, făcând loc simptomatologiei de localizare ganglionară laterocervicală, manifestată prin torticolis determinat de contractura sternocleidomastoidianului supraiacent colecției purulente și însoțit de durere și împăstare de-a lungul mușchiului, cu tumefacția dureroasă a regiunii retro- și subangulo-mandibulară.

Evoluția adenoflegmonului laterocervical profund este de obicei torpidă, fără tendință la deschidere spontană, puroiul din profunzime făcându-și cu greu drum către tegumentele cervicale, înainte sau înapoia sternocleidomastoidianului, și doar excepțional către peretele lateral. Colecția rămasă nedrenată devine sursa unor complicații extrem de grave, ca tromboflebita jugularei cu septicopiemie, mediastinită, metastaze pleuropulmonare, ulcerarea pereților, hemoragii masive și repetate, adesea mortale. După Barnett, abcesul mediastinal, sau paraesofagian, este produs în marea majoritate a cazurilor de abcesul retrofaringian sau latero-cervical, prin drenarea puroiului în cutia toracică.

Diagnosticul abcesului laterocervical profund este dificil, atât în privința precizării afecțiunii însăși, cât și a cauzelor ei.

Adenoflegmonul laterocervical profund va fi incizat pe cale externă, înaintea sau înapoia sternocleidomastoidianului, după localizarea tumefecției maxime; antibioticoterapia desigur nu poate lipsi din arsenalul terapeutic.

\section{Prezentarea cazurilor}

Obs.nr 1: Sugarul F.O. de nouă luni din mediul rural, a fost internat la secția de boli contagioase cu suspiciunea de meningită purulentă, prezentând poziția de hiperextensie, hiperpirexie, stare generală alterată cu aspect toxico-septic, redoarea cefei, vărsături la orice tentativă de alimentație. După efectuarea puncției lombare și examenul lichidului cefalorahidian, se infirmă diagnosticul de meningită și se solicită consult interdisciplinar de pediatrie și ORL. De comun acord cu medicul specialist ORL am stabilit diagnosticul de adeno-etmoidită acută supurată, suspect bacteriemie, și am instituit un tratament antiinfecțios cu antibiotice cu spectru larg. Starea sugarului rămâne neschimbată, motiv pentru care părinții solicită internarea la un eșalon superior. După 24 de ore obținem prima informație asupra diagnosticului stabilit: abces retrofaringian, stare septică. Nu ne-a rămas altceva decât să analizăm greșelile sau omisiunile noastre legate de acest caz, după cum urmează: 


\section{CAZURI CLIJ N ICE}

- lipsa de experiență, fiind primul caz grav, și cunoștințe teoretice lacunare

- incidența rară în patologia copilului, care ne determină să ne gîndim la prezumpții mai accesibile: adenoidite, amigdalite, etmoidite, sinuzite, etc.

- o simplă inspecție a peretelui posterior al faringelui nu ajută la stabilirea diagnosticului, palparea fiind esențială

- interpretarea incorectă a unor date anamnestice: nu am evaluat tratamentul timp de 1 săptămână cu antibiotice; primul simptom a fost disfagia, cu incapacitatea de a înghiți alimente solide, ulterior și lichide; pseudo-redoarea cefei a fost cauzată de un proces faringian; prezența stridorului faringean cu caractere particulare

- clarificarea porții de intrare a septicemiei

Obs. nr.2: copil școlar, de opt ani, de sex masculin a fost prezentat la serviciul nostru pentru următoarele motive: în urmă cu două săptămâni copilul a suferit de o amigdalită acută pultacee tratată cu amoxicilină+acid clavulanic timp de patru zile, după tratamentul aplicat se notează o ameliorare a tabloului de fond, însă nu și vindecare, copilul în continuare prezintă subfebrilități, este adinamic, apatic, transpiră, are apetit scăzut. După patru săptămâni de evoluție subitrantă, reapare febra la valori de 39-40 de grade, fără simptome clinice de localizare, și în următoarele 3-4 zile cu caracter septic.

Am etichetat cazul ca o bacteriemie sau septicemie cu poartă de intrare amigdaliană, instalată după un tratament inadecvat al amigdalitei. Antibioticoterapia de prima alegere a rămas ineficientă, întreținând o stare de incertitudine privind diagnosticul.

Primul simptom care a apărut a fost durerea la deglutiţie, la orice tentativă de alimentație, cu localizare prioritară în treimea inferioară a regiunii cervicale. Acest simptom a fost succedat de alte simptome locale în următoarea ordine cronologică, la un interval de 3-4 zile: torticolis drept cu caracter permanent foarte dureros; la palparea mai profundă al regiunii cervivale în partea anterioară a strenocleidomastoidianului se simte o indurație foarte dureroasă pe planuri anatomice profunde; în final apare un edem local cu localizare suprasternală.

Coroborând elementele clinice am stabilit diagnosticul de abces laterocervical drept profund, cu stare septică, confirmat și soluționat chirurgical.

\section{Concluzii}

1-Abcesul retrofaringian și abcesul laterocervical profund sunt două afecțiuni rare, dar care în cazul nedepistării în timp util pot avea consecințe grave.

2-La sugar și copilul antepreșcolar abcesul retrofaringean apare în general după adonoidite acute supurate, mai ales la copii cu diateză limfatică.

3-Simptomele se instalează după cum urmează:

-sindrom infecțios marcat

-disfagia/refuzul alimentelor solide și cele lichide ulterior

-stridorul faringean

-pseudoredoarea cefei

-stare generală profund alterată

4-Abcesul laterocervical profund este apanajul copilului școlar și adolescentului, urmând unor amigdalite incorect tratate, mai ales la copii cu imundeficiențe, sinuzite, etc.

5-Semnele de debut:

-febră de tip septic

-torticolis de partea afectată, cu caracter constant

-indurația țesuturilor profunde anterioare sau posterioare ale mușchiului sternocleidomastoidian

-infiltrația edematoasă al regiunii suprasternale în fazele mai avansate ale bolii. 


\section{Referințe}

1. Dittmer A. Pediatrische Diagnoze und Differentialdiagnose, Leipzig, VEB, Georg Thieme, 622

2. Shirkey H. Pediatric Therapy, Saint-Louis, The C.V.Mosby Company, 1975;629

3. Nelson WE. Texbook of Pediatrics, Philadelphia, W.B.Saunders Company, 1964;810

4. Păunescu C. Oto-rino-laringologie pediatrică, București, Editura Medicală, 168-172

5. Kollar D. Fül-Orr-Gege-betegsegek gyemekkorban, Budapest, Medicina Konyvkiado,168-169 